ISSN : $2406-7415$

E-ISSN : $2655-9919$

JURNAL AKUNTANSI DAN BISNIS KRISNADWIPAYANA

DOI: http://dx.doi.org/10.35137/jabk.v8i1.506

Volume 8 Nomor 1 (Januari - April) 2021

\title{
ANALISIS PERBANDINGAN PERKEMBANGAN USAHA MIKRO, KECIL DAN MENENGAH (UMKM) SEBELUM DAN SESUDAH MENDAPATKAN PEMBIAYAAN MIKRO MELALUI PROGRAM MEKAAR DI WILAYAH CAKUNG
}

\author{
Nur Amanah 1) \\ Fakultas Ekonomi Universitas Krisnadwipayana \\ Jalan Unkris Jatiwaringin Jakarta Timur \\ Email : nuramanah2314@gmail.com \\ Esti Damayanti ${ }^{2)}$ \\ Fakultas Ekonomi Universitas Krisnadwipayana \\ Jalan Unkris Jatiwaringin Jakarta Timur \\ Email : estidamayanti@unkris.ac.id
}

\begin{abstract}
Business capital is one of the things that is needed by micro, small and medium enterprises to develop a business. The purpose of this study is to analyze how the development of micro, small and medium enterprises before and after being given financing by financial institutions. The method used in this research is quantitative comparisons which are analyzed using the Paired Sample t-test analysis technique to test whether there is a difference in the mean of the two paired samples.
\end{abstract}

Keywords : Micro,Small and Medium Enterprises (MSMES),Microfinance Institutions, Sales Turnover, Profits

\section{PENDAHULUAN}

Usaha Mikro, Kecil dan Menengah (UMKM) mempunyai peran terdepan dan strategis dalam pembangunan ekonomi nasional. Selain berperan dalam pertumbuhan ekonomi dan penyerapan tenaga kerja, UMKM juga berperan dalam mendistribusikan hasil-hasil pembangunan. Berdasarkan data dari Kementerian Koperasi dan UKM RI melaporkan bahwa secara jumlah unit, UMKM memiliki pangsa sekitar 99,99\% (62.9 juta unit) dari total keseluruhan pelaku usaha di Indonesia (2017). (www.ukmindonesia.id).

Salah satu bentuk kontribusi UMKM dalam pembangunan ekonomi nasional yaitu kontribusi UMKM terhadap Produk Domestik Bruto (PDB) Nasional yang berperan serta dalam meningkatkan pendapatan negara. Menurut menteri Koperasi dan UKM Teten Masduki, sektor UMKM diakui saat ini tengah menjadi andalan pemerintah dalam meningkatkan pertumbuhan ekonomi ditengah menurunnya ekonomi global. Terbukti UMKM telah berkontribusi terhadap PDB Nasional sebesar 60,34\%, menyerap tenaga kerja sebesar $97 \%$, juga berkontribusi terhadap nilai ekspor sebesar $14,17 \%$, serta mencatat nilai investasi sebesar $58,18 \%$ (www.kemenkopukm.go.id). Kontribusi UMKM dalam perekonomian Indonesia adalah UMKM yang menjadi prioritas nasional dalam percepatan pembangunan. UMKM menjadi prioritas nasional karena dapat menyerap tenaga kerja dalam jumlah yang cukup banyak, dan menciptakan 
ISSN : $2406-7415$

E-ISSN : $2655-9919$

JURNAL AKUNTANSI DAN BISNIS KRISNADWIPAYANA

DOI: http://dx.doi.org/10.35137/jabk.v8i1.506

banyak lapangan pekerjaan sehingga berkurangnya pengangguran (Muhril, 2014). Tidak terkecuali keberadaan UMKM pada wilayah Cakung yang terletak di Jakarta Timur dan berikut ini adalah jumlah sarana perekonomian di kecamatan Cakung :

\section{Tabel 1. Jumlah Sarana Perekonomian di Kecamatan Cakung}

\begin{tabular}{lccc}
\hline \multicolumn{1}{c}{ Sarana } & $\mathbf{2 0 1 6}$ & $\mathbf{2 0 1 7}$ & $\mathbf{2 0 1 8}$ \\
\hline \multicolumn{1}{c}{$(\mathbf{1})$} & $\mathbf{( 2 )}$ & $\mathbf{( 3 )}$ & $\mathbf{( 4 )}$ \\
\hline Mini Market & 30 & 33 & 35 \\
Toko/Warung & 4282 & 4301 & 4365 \\
Restoran/Rumah Makan & 110 & 117 & 124 \\
Pasar & 26 & 27 & 29 \\
\hline Jumlah/Total & $\mathbf{4 4 4 8}$ & $\mathbf{4 4 7 8}$ & $\mathbf{4 5 5 3}$ \\
\hline Sumber : BPS Kota Administrasi Jakarta Timur & &
\end{tabular}

Dilihat dari jumlah sarana perekonomian diwilayah Cakung ini menunjukkan bahwa selalu mengalami peningkatan disetiap tahunnya. Peningkatan tertinggi terlihat pada toko ataupun warung, dimana banyak pelaku UMKM menggantungkan kesempatan usahanya pada toko atau warung yang diketahui tidak memerlukan modal besar. Hal ini membuktikan bahwa masih banyak pelaku UMKM yang menjadikan modal sebagai kendala terbesar yang dialami pada sektor usaha tersebut. Sebagian besar darinya hanya mengandalkan modal pribadi yang sangat minim sedangkan persaingan pasar ke depan semakin bertambah seiring dengan pertambahan laju pertumbuhan penduduk di Indonesia khususnya.

Aspek modal merupakan aspek penting dalam menjalankan usaha, keterbatasan modal akan membatasi ruang gerak usaha tersebut. Maka disini peran Lembaga Keuangan Mikro (LKM) sangat dibutuhkan dalam pengembangan usaha mikro melalui pemberian pinjaman modal kepada usaha mikro, kecil dan menengah.
Volume 8 Nomor 1 (Januari - April) 2021

Adapun tujuan dari lembaga keuangan mikro adalah bukan hanya menyalurkan dana bagi pelaku usaha mikro untuk meningkatkan usahanya, namun juga mampu mewujudkan pembangunan sektor usaha serta pemberdayaan usaha mikro dalam rangka penanggulangan dan pengentasan kemiskinan.

Salah satu perusahaan Lembaga Keuangan Mikro Bukan Bank yang saat ini hadir dalam memberikan akses pendanaan baik melalui pinjaman atau pembiayaan modal dalam usaha skala mikro maupun pemberian jasa konsultasi pengembangan usaha kepada UMKM adalah PT Permodalan Nasional Madani (Persero) atau lebih dikenal dengan sebutan PNM. Dengan salah satu programnya yaitu Membina Ekonomi Keluarga Sejahtera atau bisa disebut dengan Mekaar. Program Mekaar ini merupakan layanan pembiayaan PNM yang diluncurkan pada tahun 2015 untuk Pilot Project ditahun 2016 dengan target nasabah wanita pra sejahtera yang tidak memiliki modal untuk membuka usaha maupun modal untuk mengembangkan usaha dengan penyertaan pendampingan usaha.

Perkembangan UMKM menjadi penting sebagaimana telah dibahas tentang kontribusi UMKM. Dengan adanya pembiayaan yang disediakan oleh PT PNM ini diharapkan UMKM dapat mengembangkan usahanya. Perkembangan UMKM dapat dilihat dari adanya perbedaan sebelum dan sesudah menggunakan pembiayaan. Apabila ada perkembangan UMKM sesudah menggunakan pembiayaan berarti penggunaan pembiayaan tersebut berhasil. Apabila sesudah penggunaan pembiayaan tidak terjadi perkembangan berarti pembiayaan tersebut belum berhasil. 
ISSN : $2406-7415$

E-ISSN : $2655-9919$

JURNAL AKUNTANSI DAN BISNIS KRISNADWIPAYANA

DOI: http://dx.doi.org/10.35137/jabk.v8i1.506

Volume 8 Nomor 1 (Januari - April) 2021

Menurut Muhammad Sholeh (2008) perkembangan UMKM dapat diukur dengan jumlah omzet penjualan, dan keuntungan usaha. Suatu usaha dapat dikatakan berkembang apabila omzet penjualan naik, ketika omzet penjualan mengalami kenaikan berarti jumlah pendapatan juga bertambah. Ketika jumlah pendapatan bertambah maka bertambah pula jumlah keuntungan yang didapatkan.

Desakan akan kondisi ekonomi saat ini membuat para pelaku usaha mikro dan kecil (UMKM) berharap dengan adanya tambahan atau bantuan modal yang diberikan dari lembaga pembiayaan tersebut dapat berdampak pada usaha yang mereka jalankan dan dapat meningkatkan kapasitas ekonomi pelaku UMKM di sekitar, sehingga waktu produktif yang ada bisa dimaksimalkan untuk meningkatkan kesejahteraan keluarga melalui usahanya. Pembiayaan merupakan salah satu tugas bagi LKM, yaitu pemberian fasilitas penyediaan dana untuk memenuhi kebutuhan pihak-pihak yang merupakan defisit unit. Terlihat dari hasil survei masih banyak UMKM yang sudah menerima pembiayaan dari PT PNM namun tidak bisa memisahkan antara pembiayaan konsumtif dan pembiayaan produktif. Sehingga pembiayaan produktif atau tambahan modal yang diberikan tersebut menjadi terlihat tidak meningkat ataupun menurun. Berdasarkan penjelasan tersebut perlu dilakukan penelitian untuk melihat seberapa besar perubahan perkembangan usaha UMKM setelah adanya pemberian modal usaha melalui program Mekaar dan adakah perbedaan antara sebelum dan sesudah program pembiayaan tersebut diberikan.

\section{LANDASAN TEORI}

\section{Usaha Kecil Mikro dan Menengah}

Menurut Kementrian Koperasi dan UMKM dalam Aufar (2014) pengertian usaha kecil dan menengah adalah "entitas usaha yang mempunyai kekayaan bersih paling banyak Rp. 200.000.000,- tidak termasuk tanah dan bangunan tempat usaha dan memiliki penjualan tahunan paling banyak Rp. 1.000.000.000,- Sementara itu, Usaha Menengah merupakan entitas usaha milik warga Negara Indonesia yang memiliki kekayaan bersih lebih besar dari Rp. 200.000.000,- s.d Rp. 10.000.000,- tidak termasuk tanah dan bangunan"

Selain kontribusinya dalam pembangunan ekonomi Indonesia, UMKM juga memiliki beberapa kendala. Menurut Mudjarad Kuncoro dalam Harian Bisnis Indonesia pada tanggal 21 Oktober 2008 mengungkapkan bahwa ada tujuh masalah yang dihadapi oleh UMKM dalam era krisis global, yaitu :

1. Tidak adanya pembagian tugas yang jelas antara bidang administrasi dan operasi. Kebanyakan UKM dikelola oleh perorangan yang merangkap sebagai pemilik sekaligus pengelola perusahaan, serta memanfaatkan tenaga kerja dari keluarga dan kerabat dekatnya.

2. Akses industri kecil terhadap lembaga kredit formal rendah, sehingga mereka cenderung menggantungkan pembiayaan usahanya dari modal sendiri atau sumber lain, seperti keluarga, kerabat, pedagang perantara, bahkan rentenir.

3. Sebagian besar usaha kecil ditandai dengan belum dipunyainya status badan hukum. Mayoritas UMKM merupakan perusahaan perorangan yang tidak berakta notaris, $4,7 \%$ tergolong

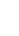


ISSN : $2406-7415$

E-ISSN : $2655-9919$

JURNAL AKUNTANSI DAN BISNIS KRISNADWIPAYANA

DOI: http://dx.doi.org/10.35137/jabk.v8i1.506

perusahaan perorangan berakta notaris, dan hanya $1,7 \%$ yang sudah memiliki badan hukum (PT/ NV,CV, Firma, atau koperasi).

4. Tren nilai ekspor menunjukkan betapa sangat berfluktuatif dan berubahubahnya komoditas ekspor Indonesia selama periode 1999-2006.

5. Pengadaan bahan baku, masalah terbesar yang dihadapi dalam pengadaan bahan baku adalah mahalnya harga, terbatasnya ketersediaan, dan jarak yang relatif jauh. Ini karena bahan baku bagi UKM yang berorientasi ekspor sebagian besar berasal dari luar daerah usahan tersebut berlokasi.

6. Masalah utama yang dihadapi dalam memenuhi kebutuhan tenaga kerja adalah tidak terampil dan mahalnya biaya tenaga kerja. Regenerasi perajin dan pekerja terampil relatif lambat. Akibatnya, di banyak sentra ekspor mengalami kelangkaan tenaga terampil untuk sektor tertentu.

7. Dalam bidang pemasaran, masalahnya terkait dengan banyaknya pesaing yang bergerak dalam industri yang sama, relatif minimnya kemampuan bahasa asing sebagai suatu

hambatan dalam melakukan negosiasi, dan penetrasi pasar diluar negeri.

Modal merupakan salah satu faktor penting dalam memulai atau meningkatkan suatu kegiatan usaha, terutama bagi golongan ekonomi lemah termasuk para pelaku Usaha Mikro, Kecil dan Menengah (UMKM). Seringkali para pelaku UMKM ini mengalami persoalan dalam hal masalah permodalan. Pada umumnya mereka memiliki usaha yang relatif kecil, sehingga banyak sekali upaya untuk melanjutkan kegiatan usahanya salah satunya yaitu
Volume 8 Nomor 1 (Januari - April) 2021

melalui pemanfaatan pinjaman kredit sebagai alternatif yang tepat untuk mengembangkan usaha. Baik melalui kredit pada lembaga keuangan bank maupun lembaga keuangan bukan bank lainnya.

\section{Pembiayaan atau Kredit}

Menurut Hasibuan (2008) kredit adalah "Semua jenis pinjaman yang harus dibayar kembali bersama bunganya oleh peminjam sesuai dengan perjanjian yang telah disepakati”.

Pengertian kredit menurut UU Perbankan No. 10 Tahun 1998 dalam Kasmir (2009) adalah "Penyediaan uang atau tagihan yang dapat dipersamakan dengan itu, berdasarkan persetujuan atau kesepakatan pinjam meminjam anatara bank dengan pihak lain yang mewajibkan pihak peminjam melunasi utangnya setelah jangka waktu tertentu dengan pemberian bunga"

Sehingga dari pengertian-pengertian kredit diatas dapat disimpulkan bahwa kredit adalah suatu perjanjian pinjam-meminjam yang dilakukan oleh dua belah pihak yaitu kreditur dan debitur dimana pihak debitur berkewajiban untuk mengembalikan pinjamannya sesuai dengan ketentuan yang telah disepakati bersama dan suku bunga yang telah ditetapkan oleh pihak kreditur.

\section{Perkembangan Usaha}

Indikator adanya perkembangan usaha dapat dilihat dari omzet penjualan dan laba atau keuntungan usaha. Menurut Oktaviani (2008) Omzet penjualan adalah"Keseluruhan jumlah penjualan barang atau jasa dalam kurun waktu tertentu yang dihitung berdasarkan jumlah uang yang diperoleh"

Dari definisi diatas tersebut dapat dikemukakan bahwa yang dimaksud dengan 
ISSN : $2406-7415$

E-ISSN : $2655-9919$

JURNAL AKUNTANSI DAN BISNIS KRISNADWIPAYANA

DOI: http://dx.doi.org/10.35137/jabk.v8i1.506

omzet penjualan adalah total jumlah pendapatan atas barang dan jasa yang dihitung berdasarkan jumlah laba bersih dari laporan laba-rugi perusahaan selama suatu masa jual. Seorang pengelola usaha dituntut untuk selalu meningkatkan omzet penjualannya sehingga dapat dilihat pertumbuhan usahanya dari hari ke hari. Hal ini diperlukan kemampuan dalam mengelola modal terutama modal usaha agar kegiatan operasional perusahaan atau pengusaha dapat terjamin kelangsungannya.

Tujuan utama pengusaha adalah memaksimalkan keuntungan atau laba. Pengertian laba secara operasional merupakan selisih antara pendapatan yang didapatkan yang timbul dari seluruh transaksi selama satu periode dengan biaya yang berkaitan dengan pendapatan dari barang atau jasa tersebut.

\section{METODE PENELITIAN}

Objek yang diteliti pada penelitian ini yaitu perkembangan usaha dengan indiaktornya berupa (1) omset penjualan dan ( 2)keuntungan dari usaha mikro dengan sasaran sektor usaha berupa toko kelontong atau warung yang paling dominan dimiliki oleh pelaku UMKM di wilayah kecamatan Cakung, tepatnya di kelurahan Cakung Timur.

Populasi dalam penelitian ini adalah UMKM yang memperoleh pembiayaan program Mekaar dari PT PNM di kecamatan Cakung tepatnya pada kelurahan Cakung Timur. Pemilihan wilayah dikelurahan cakung timur karena banyak pelaku UMKM yang memperoleh pembiayaan melalui program mekaar sudah dapat menggambarkan kondisi usahanya.
Volume 8 Nomor 1 (Januari - April) 2021

Kemudian sampel dalam penelitian ini diambil dari jumlah UMKM yang mendapatkan pembiayaan program Mekaar dari PT PNM dan yang masih dalam masa pembiayaan untuk periode Januari s/d Desember tahun 2019 dengan waktu pengembalian angsuran 50 minggu atau pada saat pembiayaan mulai pada minggu ke 17 hingga minggu ke 28 (tiga bulan) berdasarkan responden yang bisa memberikan data keuangan. Total yang dapat memberikan data keuangan tersebut sebanyak 30 sampel yang didominasi dari sektor usaha toko kelontong atau warung.

Penelitian ini merupakan penelitian kuantitatif dengan metode komparatif. Data yang diperoleh secara langsung melalui studi lapangan dan wawancara dianalisis dengan menggunakan teknik analisis $U j i$ Paired Sample t-test untuk menguji apakah ada perbedaan rata-rata dua sampel yang berpasangan. Teknik analisis ini untuk mengetahui perbedaan antara sebelum dan sesudah memperoleh pembiayaan dari program mekaar yang diberikan oleh PT PNM yang meliputi perkembangan usaha mikro dengan indikator omzet penjualan dan laba.

\section{HASIL DAN PEMBAHASAN}

\section{Omzet Penjualan}

Suatu usaha dapat dikatakan berkembang salah satunya dengan adanya kenaikan omzet penjualan. Hasil analisis menggunakan uji paired sampel t- test mengenai omzet penjualan sebelum dan sesudah menerima pembiayaan dari program mekaar dapat dilihat sebagai berikut :

\section{Tabel 2. Descriptive Output Omzet}


ISSN : $2406-7415$

E-ISSN : $2655-9919$

JURNAL AKUNTANSI DAN BISNIS KRISNADWIPAYANA

DOI: http://dx.doi.org/10.35137/jabk.v8i1.506

Volume 8 Nomor 1 (Januari - April) 2021

\begin{tabular}{lrrr}
\hline & N & \multicolumn{1}{c}{ Minimum } & Maximum \\
\hline omzet sebelum & 30 & 2250000 & 6000000 \\
omzet sesudah & 30 & 3300000 & 8400000 \\
Valid N (listwise) & 30 & & \\
\hline
\end{tabular}

Sumber : Data Primer diolah, (2019)

Berdasarkan tabel 2 di atas menunjukkan nilai minimum dan maksimum dari masing-masing kelompok data (omzet sebelum pembiayaan dan omzet sesudah pembiayaan dalam jangka waktu 3 bulan). Tampak bahwa omzet sebelum pembiayaan sebesar Rp. 2.250.000 dan maksimum sebesar Rp. 6.000.000 sedangkan nilai minimum omzet setelah pembiayaan adalah sebesar Rp. 3.300.000 dan maksimum sebesar Rp. 8.400.000.

Tabel 3. Paired Samples Statistics Output

\begin{tabular}{|c|c|c|c|}
\hline & & Mean & $\mathrm{N}$ \\
\hline \multirow[t]{2}{*}{ Pair 1} & $\begin{array}{l}\text { omzet } \\
\text { sebelum }\end{array}$ & 3871666,67 & 30 \\
\hline & $\begin{array}{l}\text { omzet } \\
\text { sesudah }\end{array}$ & 5321666,67 & 30 \\
\hline
\end{tabular}

Berdasarkan tabel Paired Samples Statistics Output Omzet di atas menunjukkan ringkasan hasil statistik deskriptif dari kedua sampel yang diteliti yakni nilai Omzet sebelum dan sesudah. Untuk nilai omzet sebelum diperoleh nilai rata-rata atau mean sebesar 3871666,67. Sedangkan untuk nilai omzet sesudah mendapatkan pembiayaan diperoleh nilai rata-rata sebesar 5321666,67. Dengan jumlah responden atau sampel yang digunakan pada penelitian ini adalah sebanyak 30 sampel. Karena nilai rata-rata omzet sebelum 3871666,67 < omzet sesudah 5321666,67, maka artinya secara deskriptif ada perbedaan rata-rata omzet penjualan antara sebelum dan sesudah mendapatkan pembiayaan dari program mekaar.

\section{Tabel 4. Paired Samples Correlations Omzet}

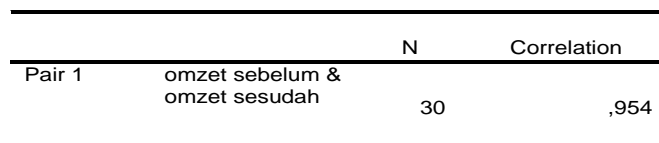

Sumber : Data Primer diolah, (2019)

Berdasarkan output diatas menunjukkan hasil uji korelasi atau hubungan antara kedua variablel yaitu omzet sebelum dan omzet sesudah mendapatkan pembiayaan. Diketahui nilai koefisien korelasi (Correlation) sebesar 0,954 dengan nilai signifikansi (Sig) sebesar 0,000. Karena nilai Sig. 0,000 < probabilitas 0,05, maka dapat dikatakan terdapat korelasi antara omzet sebelum dan sesudah mendapatkan pembiayaan.

Tabel 5. Paired Samples Test Omzet

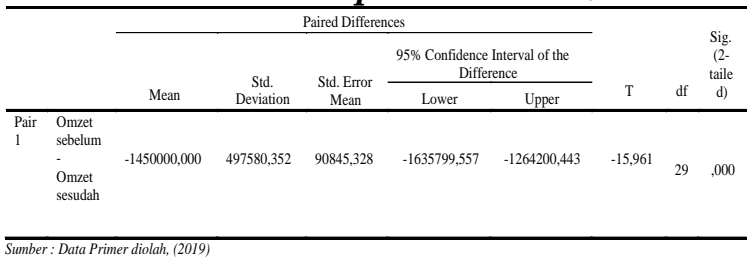

Berdasarkan hasil dari Uji Paired Sample TTest pada Omzet ini diketahui thitung bernilai negatif yaitu sebesar -15,961. thitung bernilai negatif ini disebabkan karena nilai rata-rata omzet sebelum pembiayaan lebih rendah dari pada omzet setelah pembiayaan, dalam konteks ini thitung negatif dapat bermakna positif. Sehingga nilai thitung menjadi 15,961 yang mana nilai thitung ini lebih besar dari tabel yaitu $15,961>2,045$ maka dapat disimpulkan bahwa terdapat perbedaan 
terhadap omzet penjualan dalam pemanfaatan strategi perkembangan usaha melalui bantuan modal yang diberikan oleh PT PNM..

\section{Laba}

Penambahan modal yang diikuti pada peningkatan produksi dan omzet penjualan sesudah memperoleh pembiayaan dari program Mekaar menyebabkan laba atau keuntungan para pelaku UMKM juga ikut meningkat. Hasil analisis menggunakan uji paired sampel t-test mengenai laba atau keuntungan sebelum dan sesudah menerima pembiayaan dari program mekaar dapat dilihat sebagai berikut :

\section{Tabel 6. Descriptive Output Laba}

\begin{tabular}{lcrrc}
\hline & $\mathrm{N}$ & Minimum & Maximum & \multicolumn{1}{c}{ Mean } \\
\hline laba sebelum & 30 & 1000000 & 4000000 & 2446166,67 \\
laba sesudah & 30 & 1500000 & 4600000 & 3156666,67 \\
Valid N (listwise) & 30 & & & \\
\hline Sumber : Data Primer diolah, (2019) & & &
\end{tabular}

Berdasarkan tabel descriptive di atas menunjukkan nilai mean, minimum dan maksimum dari masing-masing kelompok data (laba sebelum pembiayaan dan laba sesudah pembiayaan dalam jangka waktu 3 bulan). Tampak bahwa laba minimum sebelum pembiayaan sebesar Rp 1.000.000 dan maksimum sebesar Rp. 4.000.000 sedangkan nilai minimum laba setelah pembiayaan adalah sebesar $\mathrm{Rp}$. 1.500.000 dan maksimum sebesar Rp. 4.600.000. Nilai mean atau rata-rata laba setelah pembiayaan $\operatorname{Rp} 2.446 .167$ di mana lebih besar dari laba sebelum pembiayaan yaitu Rp 3.156.667.

\section{Tabel 7. Paired Samples Statistics Output Laba}

Copyright (c) 2021 Esti Damayanti, SE., M.Si., Nur Amanah
Volume 8 Nomor 1 (Januari - April) 2021

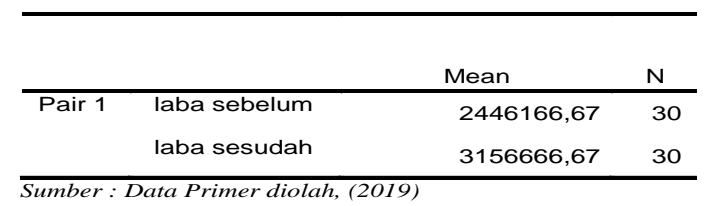

Berdasarkan tabel Paired Samples Statistics Output Laba di atas menunjukkan ringkasan hasil statistik deskriptif dari kedua sampel yang diteliti yakni nilai laba sebelum dan sesudah mendapatkan pembiayan. Untuk nilai laba sebelum diperoleh nilai rata-rata atau mean sebesar 2446166,67. Sedangkan untuk nilai laba sesudah mendapatkan pembiayaan diperoleh nilai rata-rata sebesar 3156666,67. Dengan jumlah responden yang digunakan pada penelitian ini adalah sebanyak 30 sampel. Karena nilai rata-rata laba sebelum 2446166,67 < laba sesudah 3156666,67, maka artinya secara deskriptif ada perbedaan rata-rata laba usaha antara sebelum dan sesudah mendapatkan pembiayaan dari program mekaar yang diberikan oleh PT PNM.

Tabel 8. Paired Samples Correlations Laba

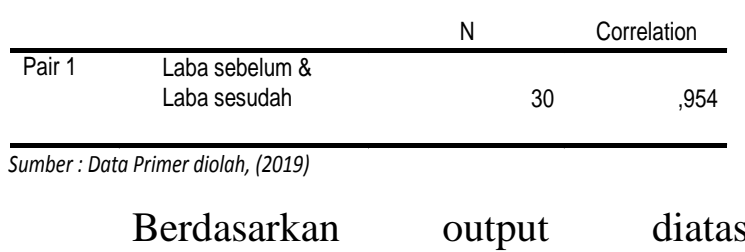
menunjukkan hasil uji korelasi atau hubungan antara kedua variablel laba sebelum dan laba sesudah mendapatkan pembiayaan. Diketahui nilai koefisien korelasi (Correlation) sebesar 0,954 dengan nilai signifikansi (Sig) sebesar 0,000. Karena nilai Sig. $0,000<$ probabilitas 0,05 , maka dapat dikatakan terdapat korelasi antara laba sebelum dan sesudah mendapatkan pembiayaan

Tabel 9. Paired Samples Test Laba 
ISSN : $2406-7415$

E-ISSN : $2655-9919$

JURNAL AKUNTANSI DAN BISNIS KRISNADWIPAYANA

DOI: http://dx.doi.org/10.35137/jabk.v8i1.506

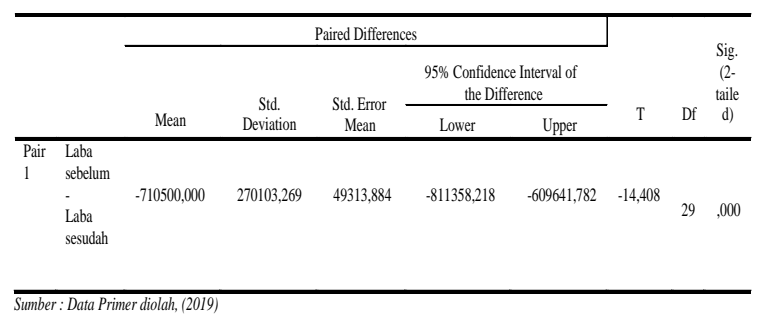

Berdasarkan hasil dari Uji Paired Sample T-Test Laba ini diketahui thitung bernilai negatif yaitu sebesar -14,408. thitung bernilai negatif ini disebabkan karena nilai rata-rata laba sebelum pembiayaan lebih rendah dari pada laba setelah pembiayaan, dalam konteks ini thitung negatif dapat bermakna positif. Sehingga nilai thitung menjadi 14,408 yang mana nilai thitung ini lebih besar dari ttabel yaitu $14,408>2,045$ maka dapat disimpulkan bahwa terdapat perbedaan terhadap laba dalam pemanfaatan strategi perkembangan usaha melalui bantuan modal yang diberikan oleh PT PNM dan berpengaruh pada indikator omzet penjualan dan laba usaha para pelaku UMKM diwilayah cakung.

\section{Pembahasan}

Responden atau sampel dalam penelitian ini diambil dari populasi yaitu jumlah UMKM yang mendapatkan pembiayaan program Mekaar dari PT PNM dan yang masih dalam masa pembiayaan untuk periode Januari s/d Desember tahun 2019 dengan waktu pengembalian atau angsuran 50 minggu. Dan lebih banyak didominasi dari jenis usaha toko kelontong atau warung yang diketahui tidak memerlukan modal besar untuk menjalankan usahanya. Dari total perhitungan sampel sebelumnya terdapat sebanyak 75 sampel, lalu peneliti memperkecil menjadi 30 sampel dengan
Volume 8 Nomor 1 (Januari - April) 2021

alasan hanya UMKM yang bisa memberikan data keuangan dari total sampel tersebut. Untuk UMKM yang memiliki jenis usaha kedai makanan sebanyak 12 responden atau $40 \%$ dan yang memiliki jenis usaha warung sebanyak 18 responden atau $60 \%$.

UMKM yang dapat dikatakan fleksibel adalah tahan terhadap segala kondisi perekonomian yang tidak menentu, salah satunya dapat dilihat pada berapa lama usaha yang dijalankan. Lama pembukaan usaha dapat mempengaruhi tingkat pendapatan, lamanya seorang pelaku usaha atau bisnis menekuni bidang usahanya akan mempengaruhi produktivitasnya, sehingga dapat menambah efisiensi dan mampu menekan biaya produksi lebih kecil dari pada hasil penjualan. Semakin lama menekuni bidang usahanya makan akan semakin meningkat pengetahuannya tentang selera ataupun perilaku konsumen. Keterampilan berdagang semakin bertambah maka akan semakin banyak pula relasi bisnis maupun pelanggan yang berhasil di jaring (Wicaksono, 2011). Pada penelitian ini ada sebanyak 30 responden yang memiliki lama usaha $<2$ tahun sebanyak 16 responden atau $53 \%$ dan yang memiliki lama usaha $2-5$ tahun sebanyak 14 responden atau $47 \%$.

Berdasarkan hasil penelitian ditemukan bahwa alasan para pelaku UMKM melakukan peminjaman pembiayaan dari program Mekaar yang diberikan oleh PT PNM adalah karena kurangnya modal pada usaha yang mereka jalankan. Maka mereka memutuskan untuk mengambil penawaran pembiayaan tersebut guna memenuhi kebutuhan modal untuk mengembangkan kapasitas usaha mereka. Jumlah pembiayaan yang paling kecil 
ISSN : $2406-7415$

E-ISSN : $2655-9919$

JURNAL AKUNTANSI DAN BISNIS KRISNADWIPAYANA

DOI: http://dx.doi.org/10.35137/jabk.v8i1.506

Volume 8 Nomor 1 (Januari - April) 2021

diterima oleh responden adalah $\mathrm{Rp}$. 2.000.000,- dan yang paling besar senilai Rp. 5.000.000,-. Dari seluruh pembiayaan yang diterima para responden digunakan untuk memenuhi kekurangan modal usahanya.

Program Mekaar ini menerapkan sistem kelompok dan tanggung renteng, yang dianggap responden penerapan sistem ini sangat meringankan akses pembiayaan yang dibutuhkan. Mayoritas responden pun tidak mengalami kesulitan dalam mengangsur pembiayaan tersebut, dan besar angsuran tidak memberatkan mereka karena adanya kegiatan satu kali dalam seminggu untuk membayar angsuran dan pembinaan usaha. Sehingga para pelaku UMKM dapat fokus terhadap perkembangan usahanya dengan memanfaatkan keuntungan pada setiap bulannya.

\section{Omzet Penjualan}

Perkembangan usaha UMKM sebelum dan sesudah mendapatkan pembiayaan mikro melalui program mekaar yang diberikan PT PNM dapat dilihat pada omzet penjualan dan laba atau keuntungan usahanya. Omzet penjualan ini dapat dilihat berupa rata-rata total penjualan yang diperoleh para pelaku UMKM tiap bulan. Berikut perkembangan rata-rata omzet penjualan sebelum dan sesudah menerima pembiayaan program Mekaar.

\section{Tabel 10. Rata-Rata Omzet Penjualan Perbulan Sebelum dan Sesudah Pembiayaan

\begin{tabular}{ccc}
\hline \multirow{2}{*}{ Bulan } & \multicolumn{2}{c}{ Rata-rata Omzet Penjualan } \\
\cline { 2 - 3 } & $\begin{array}{c}\text { Sebelum } \\
\text { (Tahun 2018) }\end{array}$ & $\begin{array}{c}\text { Sesudah } \\
\text { (Tahun 2019) }\end{array}$ \\
\hline Mei & Rp. 1.280.000,- & Rp. 1.764.000,- \\
\hline Juni & Rp. 1.296.667,- & Rp. 1.782.000,- \\
\hline Juli & Rp. 1.295.000,- & Rp. 1.775.667,- \\
\hline Total & Rp. 3.871.667,- & Rp. 5.321.667,- \\
\hline Sumber : Data Primer diolah, (2019) &
\end{tabular}

Copyright (c) 2021 Esti Damayanti, SE., M.Si., Nur Amanah
Terlihat perbedaan sebelum mendapatkan pembiayaan dari program Mekaar mempunyai rata-rata omzet penjualan sebesar Rp. 3.871.667,- dan sesudah mendapatkan pembiayaan dari program Mekaar mempunyai rata-rata omzet penjualan sebanyak Rp. 5.321.667,-Dapat disimpulkan secara rata-rata omzet penjualan mengalami peningkatan setelah mendapatkan pembiayaan.

\section{Laba}

Laba atau keuntungan adalah termasuk salah satu indikator perkembangan usaha. Dari hasil penelitian, penambahan modal yang diikuti peningkatan produksi dan omzet penjualan sesudah memperoleh pembiayaan dari program Mekaar menyebabkan keuntungan atau laba pelaku UMKM juga ikut meningkat. Berikut dapat dilihat rata-rata laba sebelum dan sesudah pembiayaan dari program Mekaar.

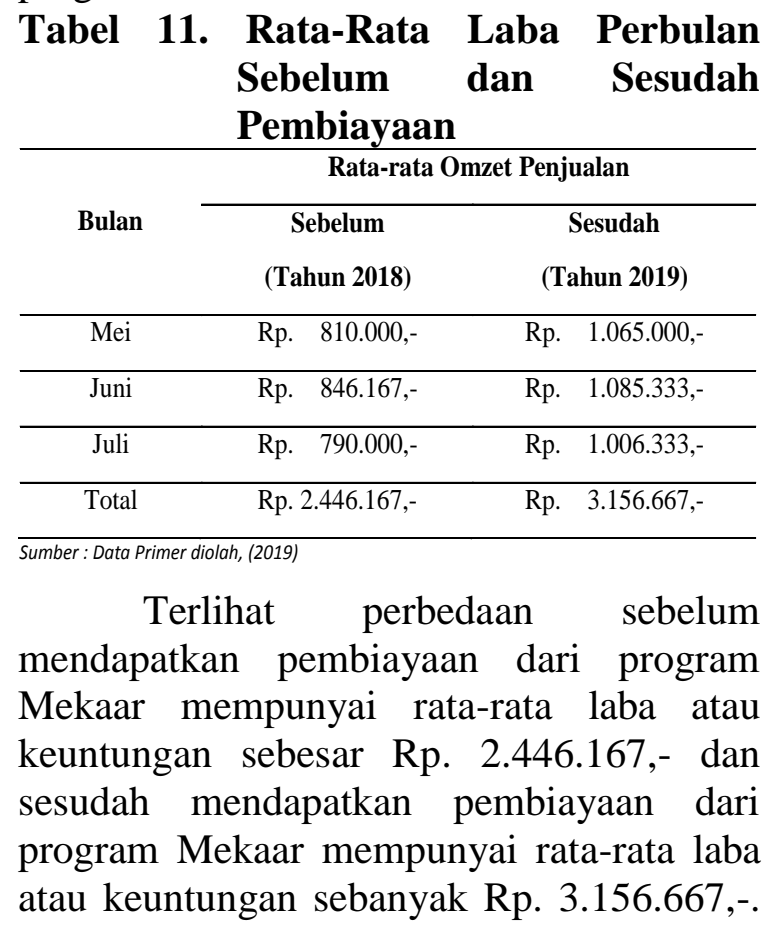


ISSN : $2406-7415$

E-ISSN : $2655-9919$

JURNAL AKUNTANSI DAN BISNIS KRISNADWIPAYANA

DOI: http://dx.doi.org/10.35137/jabk.v8i1.506

Dapat disimpulkan secara rata-rata laba atau keuntungan usaha mengalami peningkatan setelah mendapatkan pembiayaan. Sehingga dapat disimpulkan bahwa ada perbedaan rata-rata antara omzet dan laba sebelum dan sesudah mendapatkan pembiayaan dari program mekaar. Yang artinya ada perbedaan dalam pemanfaatan strategi perkembangan usaha dengan indikator omzet penjualan dan laba melalui bantuan modal yang diberikan oleh

PT PNM.

\section{Tabel 12. Hasil Perbandingan Variabel Sebelum Dan Sesudah Menerima Pembiayaan}

\begin{tabular}{lllll}
\hline \multirow{2}{*}{ No } & Variabel & \multicolumn{2}{c}{ Rata-Rata } & \\
\cline { 3 - 4 } & & & & \\
\hline 1 & Omzet Penjualan & Rp. 3.871.667,- & Rp. 5.321.667,- & $37,45 \%$ \\
\hline 2 & Laba Usaha & Rp. 2.446.167,- & Rp. 3.156.667,-- & \multirow{2}{*}{$29,04 \%$} \\
& & & & \\
\hline Sumber : Data Primer diolah, (2019) & & & \\
\hline
\end{tabular}

Indikator perkembangan usaha yang pertama adalah omzet penjualan. Perbedaan sebelum mendapatkan pembiayaan dari program Mekaar mempunyai rata-rata omzet penjualan sebesar Rp. 3.871.667,dan sesudah mendapatkan pembiayaan dari program Mekaar mempunyai rata- rata omzet penjualan sebanyak Rp. 5.321.667,-Dapat disimpulkan secara rata-rata omzet penjualan mengalami peningkatan setelah mendapatkan pembiayaan, perbedaannya adalah sebesar Rp. 1.450.000,- atau sebesar $37,45 \%$. Hal ini terlihat bahwa jumlah pelanggan bertambah dan wilayah pemasaran pun juga bertambah luas serta modal yang cukup untuk meningkatkan efektifitas usaha yang dijalankan.

Dan indikator perkembangan usaha selanjutnya adalah laba atau keuntungan usaha. Perbedaan sebelum mendapatkan
Volume 8 Nomor 1 (Januari - April) 2021

pembiayaan dari program Mekaar mempunyai rata-rata laba atau keuntungan sebesar Rp. 2.446.167,- dan sesudah mendapatkan pembiayaan dari program Mekaar mempunyai rata-rata laba atau keuntungan sebanyak Rp. 3.156.667,-. Dapat disimpulkan secara rata-rata laba atau keuntungan usaha mengalami peningkatan setelah mendapatkan pembiayaan, perbedaannya adalah sebesar Rp. 710.500,atau sebesar $29,04 \%$. Artinya rata-rata tingkat profitabilitas UMKM tersebut ada kenaikan dibandingkan dengan sebelum memperoleh pembiayaan dari program mekaar.

\section{KESIMPULAN DAN SARAN}

\section{Kesimpulan}

Dari hasil penelitian tentang analisis perkembangan usaha mikro, kecil, dan menengah sebelum dan sesudah mendapatkan pembiayaan mikro melalui program mekaar diwilayah cakung dapat disimpulkan bahwa :

1. Terdapat perkembangan antara omzet penjualan sebelum dan sesudah pembiayaaan. Omzet penjualan sesudah mendapatkan pembiayaan lebih baik dibanding dengan omzet penjualan sebelum mendapatkan pembiayaan. Perbedaan sebelum mendapatkan pembiayaan dari program Mekaar mempunyai rata-rata omzet penjualan sebesar Rp. 3.871.667,-- dan sesudah mendapatkan pembiayaan dari program Mekaar mempunyai rata-rata omzet penjualan sebanyak Rp. 5.321.667,-Dapat disimpulkan secara rata-rata omzet penjualan mengalami 
ISSN : $2406-7415$

E-ISSN : $2655-9919$

JURNAL AKUNTANSI DAN BISNIS KRISNADWIPAYANA

DOI: http://dx.doi.org/10.35137/jabk.v8i1.506

peningkatan setelah mendapatkan

pembiayaan, perbandingannya adalah sebesar Rp. 1.450.000,- atau sebesar $37,45 \%$.

2. Terdapat perbandingan antara laba atau keuntungan sebelum dan sesudah mendapatkan pembiayaan. Laba atau keuntungan sesudah mendapatkan pembiayaan dari program Mekaar yang diberikan oleh PT PNM lebih baik dibanding dengan jumlah laba atau keuntungan sebelum adanya pembiayaan. Perbedaan sebelum mendapatkan pembiayaan dari program Mekaar mempunyai rata-rata laba atau keuntungan sebesar Rp. 2.446.167,dan sesudah mendapatkan pembiayaan dari program Mekaar mempunyai ratarata laba atau keuntungan sebanyak Rp. 3.156.667,-. Dapat disimpulkan secara rata-rata laba atau keuntungan usaha mengalami peningkatan setelah mendapatkan pembiayaan, perbandingannya adalah sebesar Rp. 710.500 ,- atau sebesar 29,04\%.

\section{Saran}

Berikut ini beberapa saran berdasarkan temuan yang ada, yaitu :

1. Untuk meningkatkan usaha para pelaku UMKM disini modal berperan penting untuk menambahkan segala keperluan usahanya yang dapat meningkatkan pendapatan. Namun bagi UMKM agar dapat memperbaiki laporan atau catatan keuangannya dengan memisahkan antara pembiayaan konsumtif dan pembiayaan produktif. Pembiayaan konsumtif yang digunakan untuk memenuhi kebutuhan konsumsi
Volume 8 Nomor 1 (Januari - April) 2021

sehari-hari sedangkan pembiayaan produktif yang digunakan untuk pembiayaan modal kerja maupun investasi. Sehingga dapat terlihat perkembangan usahanya dengan membandingkan antara sebelum dan sesudah mendapatkan pembiayaan.

2. Untuk lembaga pembiayaan semoga bisa mempertahankan pembiayaan yang disalurkan guna membantu perekonomian UMKM sehingga dapat mengakses modal yang dapat mendukung usahanya. Penambahan modal yang diikuti pada peningkatan produksi dan omzet penjualan membuat laba atau keuntungan yang didapat oleh para pelaku UMKM pun meningkat. Hal ini merasa sangat menguntungkan bagi para pelaku UMKM yang mendapatkan pembiayaan dari program Mekaar tersebut untuk menjalankan usahanya

3. Bagi peneliti selanjutnya, perlu menambahkan variabel lain selain dua variabel dalam peneltian ini misalkan Ongkos Produksi, Jumlah Aset dan lain lain serta mengkaitkan dengan besaran nilai pembiayaan yang didapatkan.

\section{DAFTAR PUSTAKA}

Anoraga, Pandji dan Sudantoko Djoko, (2014). Koperasi Kewirausahaan, dan Usaha Kecil, Rineka Cipta. Jakarta

Aufar, Arizali. (2014). Faktor-faktor yang Mempengaruhi Penggunaan Informasi Akuntansi pada UMKM (Survei Pada

.


ISSN : $2406-7415$

E-ISSN : $2655-9919$

JURNAL AKUNTANSI DAN BISNIS KRISNADWIPAYANA

DOI: http://dx.doi.org/10.35137/jabk.v8i1.506

Volume 8 Nomor 1 (Januari - April) 2021

Perusahaan Rekanan PT. PLN

(Persero) di Kota Bandung)

Badan Pusat Statistik Administrasi Jakarta

Timur (2019). Jumlah Sarana

Perekonomian di Kecamatan Cakung, www.bps.go.id

Badan Pusat Statistik Kota Jakarta Timur (2019). Jumlah Usaha Kecil Dan Menengah (UKM) Menurut Bidang Usaha di Kecamatan Cakung, www.bps.go.id

Harahap, Sofyan Syafri, (2015). Analisis

Kritis atas Laporan Keuangan. Edisi 1 -

10. Jakarta: Rajawali Pers

Hasibuan S.P, Malayu (2008). Dasar-dasar

Perbankan, Jakarta: PT. Grafindo

Henny Nofianti (2013). Dampak

Pembiayaan UMKM oleh Bank

Perkreditan Rakyat di Bali Terhadap

Kinerja UMKM. E-Jurnal Ekonomi dan Bisnis Universitas Udayana

Kasmir, (2009). Bank dan Lembaga Keuangan Lainnya, Jakarta: PT. Raja Grafindo Persada

Kasmir, (2012). Analisis Laporan

Keuangan, Jakarta: PT. Raja Grafindo

Persada

Kementrian Koperasi dan Usaha Kecil dan

Menengah Republik Indonesia,

Perkembangan Data Usaha Mikro,

Kecil dan Menengah (UMKM) Dan

Usaha Besar (UB) tahun 2017-2018,

www.kemenkopukm.go.id

Keputusan Menteri Keuangan Nomor

316/KMK 016/1994. Pengertian

Usaha Mikro, Kecil dan Menengah

(UMKM). Jakarta

Mudrajad Kuncoro dalam Harian Bisnis

Indonesia pada tanggal 21 Oktober

2008 Munawir, (2006). Analisa
Laporan Keuangan. Yogyakarta:

Liberty

Rizkia, Nailah. (2018). Analisis Perkembangan Usaha Mikro Kecil dan Menengah (UMKM) Sebelum dan Sesudah Memperoleh Pembiayaan dari Bank Umum Syariah, Skripsi, Jakarta : Universitas Islam Negeri Syarif Hidayatullah

Siska Oktaviani, (2008). Hubungan Modal Kerja Fungsional dengan Omzet Penjualan pada Koperasi Unit Desa 'Karya Kita' Tomboali Tahun 1999. 2003. Jurnal Umum

Soeharto Prawirokusumo, (2010). Kewirausahaan dan Manajemen Usaha Kecil Edisi Pertama, Yogyakarta: BPFE UGM

Sri Lestari, (2009). Perkembangan dan Strategi Pengembangan Pembiayaan Usaha Mikro, Kecil dan Menengah (UMKM). Jurnal Pengkajian Koperasi dan UKM. Volume 4 Agustus

Sugiyono, (2014). Metode Penelitian Kuantitatif, Kualitatif, dan Kombinasi (Mixed Methods). Bandung: Alfabeta

Sugiyono, (2015). Metode Penelitian Bisnis Bandung: Cetakan Kelima, ALFABETA

UKM Indonesia, Mengenai Jumlah Unit $U M K M$, www.ukmindonesia.id Undang-Undang Republik Indonesia Nomor 1 Tahun 2013. Tentang Lembaga Keuangan Mikro.

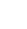


ISSN : $2406-7415$

E-ISSN : 2655 - 9919

JURNAL AKUNTANSI DAN BISNIS KRISNADWIPAYANA

DOI: http://dx.doi.org/10.35137/jabk.v8i1.506

Volume 8 Nomor 1 (Januari - April) 2021 